\title{
Perbedaan Status Gizi dan Perawakan Pendek pada Anak Sakit Perut Berulang dengan Helicobacter Pylori Positif dan Negatif
}

\author{
Vanda Elfira, Dwi Prasetyo, Dzulfikar DLH, Kusnandi Rusmil \\ Departemen Ilmu Kesehatan Anak Fakultas Kedokteran Universitas Padjadjaran/Rumah Sakit Dr. Hasan Sadikin, Bandung
}

\begin{abstract}
Latar belakang. Sakit perut berulang (SPB) merupakan keluhan yang paling sering pada anak. Infeksi Helicobacter pylori (H. pylori) saat ini merupakan salah satu penyebab organik terbanyak pada anak SPB. Infeksi $H$. pylori dapat menyebabkan malnutrisi dan perawakan pendek, tetapi hal ini masih kontroversial.

Tujuan. Mengetahui perbedaan status gizi dan perawakan pendek antara anak SPB dengan infeksi $H$. pylori positif dan negatif. Metode. Penelitian potong lintang analitik dilakukan pada anak SMP dan SMA di Bandung yang mengalami SPB. Infeksi $H$. pylori berdasarkan pemeriksaan serologis menggunakan kit BioM pylori. Analisis perbedaan status gizi dan perawakan pendek antara anak SPB dengan infeksi $H$. pylori positif dan negatif menggunakan uji chi square.

Hasil. Terdapat 224 subjek mengalami SPB dari 1658 subjek yang disurvey. Sebanyak 99 subjek memenuhi kriteria inklusi. $H$. pylori positif pada 45 subjek. Uji beda memperlihatkan perbedaan proporsi pada status gizi kurang dan infeksi $H$. pylori positif, namun belum bermakna secara statistik. Pada uji beda perawakan pendek dengan infeksi $H$. pylori positif tidak didapatkan perbedaan bermakna.

Kesimpulan. Tidak terdapat perbedaan bermakna status gizi dan perawakan pendek pada anak SPB dengan infeksi $H$. pylori positif dan infeksi H. pylori negatif. Sari Pediatri 2019;20(5):303-8
\end{abstract}

Kata kunci: sakit perut berulang, Helicobacter pylori, status gizi, perawakan pendek, anak

\section{Differences of Nutritional Status and Short Stature between Recurrent Abdominal Pain Child with Positive and Negative Helicobacter Pylori}

Vanda Elfira, Dwi Prasetyo, Dzulfikar DLH, Kusnandi Rusmil

Background. Recurrent abdominal pain (RAP) is a common problem among children. Helicobacter pylori infection (H. pylori) is currently one of the largest organic causes in children with RAP. The effects of $\mathrm{H}$. pylori infection on malnutrition and short stature are a controversial issue.

Objective. To evaluate the differences of nutritional status and short stature between RAP child with positive and negative H. pylori infection

Methods. Analytical cross-sectional study was conducted on junior high and high school children in Bandung who experienced RAP. $\mathrm{H}$. pylori infection based on serological examination using BioM pylori kit (local antigen of Mataram). Analysis of differences between nutritional status and short stature and RAP children with positive and negative $\mathrm{H}$. pylori infection using chi-square.

Results. There were 224 subjects experiencing SPB of 1658 subjects surveyed. A total of 99 subjects met the inclusion criteria. H. pylori were positive on 45 subjects. The different test showed different proportion between malnutrition in RAP children with positive H. pylori infection but no statistically significant differences. The different test showed no significant differences between short stature in RAP children with positive H. pylori infection.

Conclusions. There was no significant difference in nutritional status and short stature in RAP children with positive H. pylori infection and negative H. pylori infection. Sari Pediatri 2019;20(5):303-8

Keywords: recurrent abdominal pain, Helicobacter pylori, malnutrition, short stature, children

Alamat korespondensi: Vanda Elfira. Bagian Ilmu Kesehatan Anak FK UNPAD/ RS Dr Hasan Sadikin Bandung. Jl. Pasteur 38, Bandung, Indonesia. Telepon/ Fax: (022) 2035957, E-mail: vanda.elfira@yahoo.co.id 
S akit perut berulang (SPB) merupakan keluhan yang paling sering pada anak. ${ }^{1}$ Sakit perut berulang adalah serangan sakit perut yang terjadi minimal 3 kali dalam jangka waktu 3 bulan berturut-turut dan mengganggu aktivitas sehari-hari, seperti kehadiran di sekolah, aktivitas sosial, partisipasi dalam olahraga dan kegiatan ekstra kurikular. ${ }^{1-3}$ Penyebab SPB sebagian besar disebabkan oleh gangguan fungsional, sebagian kecil disebabkan oleh kelainan organik. ${ }^{4}$ Penyebab organik sakit perut berulang di antaranya infeksi Helicobacter pylori $(H$. pylori). ${ }^{1}$ Infeksi $H$. pylori merupakan infeksi bakteri yang paling sering terjadi pada hampir $50 \%$ dari populasi dunia. Biasanya didapat pada masa anak dan berhubungan dengan faktor sosiodemografik, seperti status sosioekonomi rendah, higiene yang buruk, dan penduduk padat. ${ }^{5}$

Hubungan antara $H$. pylori dengan malnutrisi, perawakan pendek, gastritis kronis, hypochlorhydria, dan diare kronis masih merupakan kontroversi. ${ }^{6,7}$ Seperti pada penyakit kronis lainnya, infeksi $H$. pylori dapat menyebabkan malnutrisi dan memengaruhi pertumbuhan, ${ }^{8,9}$ pada beberapa penelitian melaporkan hubungan infeksi $H$. pylori dengan malnutrisi dan perawakan pendek. ${ }^{8,10}$ Namun, pada beberapa penelitian lain didapatkan tidak ada hubungan yang bermakna antara infeksi $H$. pylori dengan status gizi dan tinggi badan. ${ }^{11}$

Pada penelitian ini peneliti ingin mengetahui perbedaan status gizi dan perawakan pendek pada anak SPB dengan infeksi $H$. pylori positif dan negatif, meliputi malnutrisi dan perawakan pendek.

\section{Metode}

Penelitian ini adalah penelitian observasional analitik pada anak SPB di Sekolah Menengah Pertama (SMP) dan Sekolah Menengah Atas (SMA), Bandung, pada bulan Agustus sampai dengan September 2017. Penelitian ini telah disetujui oleh komite etik Fakultas Kedokteran Universitas Padjadjaran. Kriteria inklusi penelitian ini adalah usia 12-18 tahun, mempunyai keluhan SPB, orangtua menyetujui mengikutsertakan anaknya dalam penelitian. Kriteria ekslusi adalah anak dengan penyakit kronis, anak yang tidak datang saat pengambilan darah. Orangtua anak yang memenuhi kriteria inklusi mengisi lembar persetujuan, dan diperiksakan IgG anti $H$. pylori dengan menggunakan
BioM pylori kit (antigen lokal Mataram) yang mempunyai sensitivitas $95 \%$ dan spesifitas $92 \% .^{12}$ Dilakukan pengukuran antropometri (berat badan dan tinggi badan) dan status gizi berdasarkan indeks massa tubuh (IMT) per usia. Sakit perut berulang (SPB) adalah sakit perut yang terjadi minimal 3 kali selama paling sedikit 3 bulan dan mengganggu aktivitas sehari-hari. Infeksi $H$. pylori positif bila hasil pemeriksaan serologis Ig G positif. Status gizi meliputi malnutrisi sedang indeks massa tubuh (IMT) menurut usia <-2 SD dan $>-3$ SD pada WHO z-score standard reference 2007), malnutrisi sedang (indeks massa tubuh-menurut-usia $<-3$ SD pada WHO z-score standard reference 2007), gemuk (overweight) (IMT menurut usia $>2 \mathrm{SD}$ pada $\mathrm{WHO}$ $z$-score standard reference 2007), dan sangat gemuk (obese) (IMT menurut usia $>3$ SD pada WHO z-score standard reference 2007). Dinyatakan sebagai gizi kurang (malnutrisi sedang dan berat), normal, dan gizi lebih (gemuk dan sangat gemuk). Perawakan meliputi pendek (stunted) (tinggi badan menurut usia $<-2$ SD pada WHO z-score standard reference 2007) dan sangat pendek (severely stunted) (tinggi badan menurut usia <-3 SD pada WHO z-score standard reference 2007). Dinyatakan sebagai normal, pendek dan sangat pendek.

Uji kemaknaan untuk membandingkan karakteristik dua kelompok penelitian digunakan uji chi-square. Analisis statistik menggunakan analisis multivariat regresi logistik mendapatkan faktor yang memengaruhi. Usia, infeksi $H$. pylori, pendidikan ibu dan status sosioekonomi merupakan faktor yang berpengaruh pada penelitian ini. Semua variabel perancu dilakukan analisis bivariat dengan nilai $\mathrm{p}<0,25$ dilanjutkan dengan analisis multivariat, dikatakan bermakna apabila nilai $\mathrm{p}<0,05$. Analisis data menggunakan SPSS ver 21 for windows.

\section{Hasil}

Terdapat jumlah total 1658 siswa dan yang memiliki keluhan SPB sejumlah 224 anak, yang memenuhi kriteria inklusi 99 anak. Hasil pemeriksaan dengan menggunakan metode serologi diperoleh $H$. pylori positif 45 anak. Berdasarkan hal tersebut maka prevalensi subjek SPB 13,5\% dan prevalensi $H$. pylori anak dengan SPB 45,4\%. Karakteristik umum tertera pada Tabel 1. Sakit perut berulang 
didapatkan paling banyak pada pasien yang berjenis kelamin perempuan. Kelompok usia paling banyak adalah 15-18 tahun. Hampir sebagian besar anak mempunyai status gizi normal dan perawakan normal. Karakteristik orangtua menunjukkan ratarata pendidikan ibu menengah, ibu tidak bekerja dan status sosioekonomi tinggi.

Pada Tabel 2 tertera hubungan karakteristik baik anak maupun ibu dengan status gizi dan perawakan pendek.

Pada Tabel 3, analisis multivariat usia 15-18 tahun merupakan faktor risiko terjadinya gizi kurang dengan besaran risiko 10,527 bila dibandingkan dengan usia 12-14 tahun. Untuk H. Pylori, tidak bermakna secara statistik, tetapi dilihat dari besarnya prevalen odds ratio

Tabel 1 Karakteristik subjek penelitian

\begin{tabular}{|c|c|c|}
\hline Karakteristik & Jumlah & $\%$ \\
\hline \multicolumn{3}{|l|}{ Anak } \\
\hline \multicolumn{3}{|l|}{ Jenis kelamin } \\
\hline Laki-laki & 12 & 12,1 \\
\hline Perempuan & 87 & 87,9 \\
\hline \multicolumn{3}{|l|}{ Usia (tahun) } \\
\hline $12-14$ & 49 & 49,5 \\
\hline $15-18$ & 50 & 50,5 \\
\hline \multicolumn{3}{|l|}{ Status gizi } \\
\hline Gizi kurang & 11 & 11,1 \\
\hline Normal & 78 & 78,8 \\
\hline Lebih & 10 & 10,1 \\
\hline \multicolumn{3}{|l|}{ Perawakan } \\
\hline Pendek & 10 & 10,1 \\
\hline Normal & 89 & 89,9 \\
\hline \multicolumn{3}{|l|}{ Infeksi $H$. pylori } \\
\hline Positif & 45 & 45,5 \\
\hline Negatif & 54 & 54,5 \\
\hline \multicolumn{3}{|l|}{ Orangtua } \\
\hline \multicolumn{3}{|l|}{ Pendidikan ibu } \\
\hline Rendah & 29 & 29,3 \\
\hline Menengah & 42 & 42,4 \\
\hline Tinggi & 28 & 28,3 \\
\hline \multicolumn{3}{|l|}{ Pekerjaan ibu } \\
\hline Tidak bekerja/IRT & 72 & 72,7 \\
\hline Bekerja & 27 & 27,3 \\
\hline \multicolumn{3}{|l|}{ Sosioekonomi } \\
\hline Rendah & 33 & 33,3 \\
\hline Sedang & 27 & 27,3 \\
\hline Tinggi & 39 & 39,4 \\
\hline
\end{tabular}

(POR) 2,468 artinya dengan infeksi $\mathrm{H}$. pylori positif berisiko gizi kurang 2,468 kali dibandingkan dengan H. pylori negatif.

Pada Tabel 4, dari dua variabel yg berhubungan dengan perawakan pendek secara bivariabel tampak secara multivariabel tidak menunjukkan ada hubungan yang bermakna ( $p>0,05)$, jika dilihat dari POR tampak untuk ibu yg bekerja memiliki risiko anak perawakan pendek sebesar 3,338 kali bila dibandingkan dengan ibu tidak bekerja.

\section{Pembahasan}

Prevalensi subjek SPB adalah 13,5\%. Angka prevalensi ini sama dengan penelitian metaanalisis tahun $2015,{ }^{2}$ hampir sama dengan angka prevalensi SPB di Inggris, Amerika Utara, Eropa, Malaysia, Bangladesh, dan di Srilangka dengan kisaran prevalensi 10\%-19\%.,13-15 Pada penelitian ini didapatkan angka prevalensi infeksi H. pylori anak SPB 45,4\%. Angka ini sedikit lebih rendah dibanding dengan angka prevalensi infeksi H. pylori anak SPB pada penelitian serupa di Jakarta (54,8\%) dan di Bandung (54,6\%). ${ }^{16,17}$

Berdasarkan karakteristik umum penelitian, terbanyak didapatkan anak perempuan dengan SPB $(87,9 \%)$. Hasil ini sesuai dengan yang dikemukakan dari berbagai kepustakaan bahwa kejadian SPB lebih banyak pada anak perempuan dibandingkan laki-laki. Kelompok usia paling banyak ialah usia 15-18 tahun, hampir sebagian besar anak mempunyai status gizi normal dan perawakan normal. Karakteristik orangtua pada anak SPB didapatkan rata-rata pendidikan ibu menengah, dan status sosioekonomi tinggi. Hasil penelitian kami berbeda dengan berbagai penelitian yang melaporkan bahwa tingkat pendidikan, tingkat sosioekonomi termasuk tingkat pendapatan merupakan faktor risiko terjadinya infeksi $H$. pylori. ${ }^{18}$

Penelitian kami memiliki hasil yang sama dengan penelitian di Iran dan Kota Izmir, Turki, yang melaporkan bahwa tidak didapatkan hubungan antara infeksi $H$. pylori dengan parameter pertumbuhan, didapatkan pada anak dispepsia dengan $H$. pylori positif maupun negatif mempunyai status gizi dan perawakan yang lebih rendah dibandingkan dengan grup kontrol yang sehat. Penelitian ini juga mendukung hipotesis bahwa anak dengan gejala dispepsia mengonsumsi kalori yang lebih sedikit sehingga dapat menyebabkan malnutrisi. ${ }^{11,19}$ 
Vanda Elfira dkk: Perbedaan status gizi dan perawakan pendek pada anak sakit perut berulang dengan helicobacter pylori positif dan negatif

Tabel 2. Hubungan karakteristik dengan status gizi anak dan perawakan pendek

\begin{tabular}{|c|c|c|c|c|c|c|c|}
\hline \multirow[b]{2}{*}{ Karakteristik } & \multicolumn{3}{|c|}{ Status gizi } & \multicolumn{4}{|c|}{ Perawakan } \\
\hline & $\begin{array}{c}\text { Kurang } \\
(\mathrm{n}=11)\end{array}$ & $\begin{array}{c}\text { Normal } \\
(\mathrm{n}=78)\end{array}$ & $\begin{array}{l}\text { Lebih } \\
(\mathrm{n}=10)\end{array}$ & $\begin{array}{c}\text { Nilai } \\
\mathrm{p}^{*}\end{array}$ & $\begin{array}{c}\text { Pendek } \\
(\mathrm{n}=10)\end{array}$ & $\begin{array}{c}\text { Normal } \\
(\mathrm{n}=89)\end{array}$ & $\begin{array}{c}\text { Nilai } \\
\mathrm{p}^{*}\end{array}$ \\
\hline Jenis kelamin & & & & 0,800 & & & 0,605 \\
\hline Laki-laki & 2 & 9 & 1 & & 0 & 12 & \\
\hline Perempuan & 9 & 69 & 9 & & 10 & 77 & \\
\hline Usia (tahun) & & & & $0,005^{*}$ & & & 0,741 \\
\hline $12-14$ & 1 & 45 & 3 & & 4 & 45 & \\
\hline $15-18$ & 10 & 33 & 7 & & 6 & 44 & \\
\hline H. pylori & & & & 0,075 & & & 0,106 \\
\hline Positif & 8 & 31 & 6 & & 2 & 43 & \\
\hline Negatif & 3 & 47 & 4 & & 8 & 46 & \\
\hline $\begin{array}{l}\text { Pendidikan } \\
\text { Ibu }\end{array}$ & & & & 0,078 & & & 0,653 \\
\hline Rendah & 2 & 26 & 1 & & 4 & 25 & \\
\hline Menengah & 3 & 35 & 4 & & 3 & 39 & \\
\hline Tinggi & 6 & 17 & 5 & & 3 & 25 & \\
\hline Pekerjaan ibu & & & & 0,447 & & & 0,130 \\
\hline Tidak bekerja/IRT & 7 & 59 & 6 & & 5 & 67 & \\
\hline Bekerja & 4 & 19 & 4 & & 5 & 22 & \\
\hline Sosioekonomi & & & & 0,015 & & & 0,833 \\
\hline Rendah & 2 & 31 & 0 & & 4 & 29 & \\
\hline Sedang & 4 & 19 & 4 & & 2 & 25 & \\
\hline Tinggi & 5 & 28 & 6 & & 4 & 35 & \\
\hline
\end{tabular}

Keterangan: uji Chi-kuadrat, ${ }^{*}$ signifikan jika $\mathrm{p}<0,05$

Tabel 3. Hubungan $H$. pylori dan faktor lainnya dengan gizi kurang berdasarkan analisis regresi logistik ganda

\begin{tabular}{lcccc}
\hline Variabel & Koef (B) & SE (B) & Nilai P & POR (IK 95\%) \\
\hline Usia (15-18) & 2,354 & 1,185 & 0,047 & $10,527(1,032-107,394)$ \\
& & & & \\
& 0,903 & 0,752 & 0,229 & $2,468(0,566-10,767)$ \\
$\begin{array}{l}H . \text { pylori (positif) } \\
\text { Pendidikan ibu }\end{array}$ & & & & \\
$\quad$ Menengah & $-0,376$ & 1,210 & 0,756 & $0,687(0,064-7,363)$ \\
$\quad$ Tinggi & 0,297 & 1,300 & 0,819 & $1,346(0,105-17,206)$ \\
Sosioekonomi & & & & \\
$\quad$ Sedang & 0,408 & 1,208 & 0,735 & $1,504(0,141-16,062)$ \\
$\quad$ Tinggi & $-0,413$ & 1,257 & 0,743 & $0,662(0,056-7,778)$ \\
\hline
\end{tabular}

Keterangan : ${ }^{\text {a }}$ referensi pendidikan dasar ; ${ }^{\text {b }}$ referensi sosioekonomi rendah; POR = prevalens Odds Ratio

Tabel 4. Hubungan $H$. pylori dan faktor lainnya dengan perawakan pendek berdasarkan analisis regresi logistik ganda

\begin{tabular}{lcccc}
\hline \multicolumn{1}{c}{ Variabel } & Koef (B) & SE (B) & Nilai P & POR (IK 95\%) \\
\hline H. pylori (positif) & $-1,402$ & 0,832 & 0,092 & $0,246(0,048-1,257)$ \\
Pekerjaan ibu (bekerja) & 1,205 & 0,697 & 0,084 & $3,338(0,852-13,075)$ \\
\hline
\end{tabular}

Keterangan : ${ }^{\text {) }}$ referensi pendidikan dasar ${ }^{b}$ ) referensi pendapatan rendah 
Hasil penelitian kami ini berbeda dengan berbagai penelitian yang melaporkan bahwa infeksi $H$. pylori berhubungan dengan status gizi dan perawakan pendek. Penelitian pada populasi anak yang menyatakan bahwa infeksi $H$. pylori berhubungan dengan perawakan pendek dan status gizi dilakukan di Turki, Italia, Peru, Kolombia, dan Korea. Hal tersebut mungkin karena metode penelitian yang kami terapkan berbeda. Keempat penelitian di negara tersebut dilakukan secara case control dan kohort, dan diikuti kecepatan pertumbuhannya. Sebaliknya, pada penelitian kami dilakukan secara potong lintang yang hanya mengukur tinggi badan dan status gizi pada saat itu. Pada penelitian di Turki dengan metode kohort selama 1 tahun didapatkan tinggi badan dan kecepatan pertumbuhan pada infeksi $H$. pylori jangka panjang $>6$ bulan lebih rendah dibandingkan yang menderita infeksi $H$. pylori $\leq 6$ bulan. $^{7}$

Pada penelitian di Italia, didapatkan $16,3 \%$ anak dengan $H$. pylori positif tinggi badan $<$ P25 dibandingkan dengan 7,8\% anak dengan $H$. pylori negatif, tetapi secara statistik tidak bermakna walaupun anak dengan $H$. pylori positif cenderung lebih pendek dibandingkan dengan $H$. pylori negatif. Perbedaan ini menjadi bermakna pada kelompok anak yang lebih tua, didapatkan $16,3 \%$ anak dengan $H$. pylori positif tinggi badan <P25 dibandingkan dengan anak dengan $H$. pylori negatif. Pada anak usia 8,5-14 tahun didapatkan $25,8 \%$ anak dengan $H$. pylori positif mempunyai tinggi badan $<\mathrm{P} 25$ dibandingkan dengan $H$. pylori negatif. Dengan demikian didapatkan hipotesis bahwa infeksi $H$. pylori dapat memengaruhi pertumbuhan pada anak yang usia lebih besar berhubungan dengan infeksi kronis dibandingkan dengan anak dengan usia lebih muda yang baru mendapatkan infeksi $H$. pylori. Hasil penelitian ini konsisten dengan hipotesis bahwa infeksi $H$. pylori yang didapat pada masa kanakkanak, membutuhkan beberapa tahun untuk dapat memengaruhi pertumbuhan. ${ }^{8}$ Perbedaannya dengan penelitian kami adalah subjek penelitian kami anak sekolah usia 12-18 tahun dengan gejala sakit perut berulang dan dengan jumlah sampel yang lebih sedikit.

Pada penelitian di Peru, dengan metode penelitian case control pada anak dengan serokonversi, $H$. pylori negatif menjadi positif. Setelah 2 bulan terinfeksi didapatkan bahwa kenaikan berat badan lebih 24\% lebih rendah dibandingkan pada anak yang $H$. pylori tetap negatif pada kelompok usia $>2$ tahun. ${ }^{20}$ Sementara pada penelitian di Kolombia, dilakukan secara kohort selama 2,5 tahun pada anak yang pada mulanya tidak terinfeksi $H$. pylori. Setelah itu, selama pemantauan anak menjadi terinfeksi $H$. pylori dan didapatkan kecepatan pertumbuhan berkurang hingga $0,042 \pm 0,014 \mathrm{~cm} /$ bulan. Kecepatan pertumbuhan berkurang mulai terlihat setelah terpapar infeksi setelah 1-2 bulan. ${ }^{6}$ Penelitian di Korea pada populasi anak sehat usia 10-15 tahun didapatkan hasil rata-rata tinggi badan yang lebih rendah pada infeksi $H$. pylori yang disertai dengan anemia defisiensi besi pada anak masa pubertas. ${ }^{21}$

Analisis regresi logistik ganda dilakukan berdasarkan analisis hubungan berbagai faktor yang diteliti dengan status gizi. Hasil analisis didapatkan secara multivariabel menunjukkan bahwa infeksi $H$. pylori positif berisiko gizi kurang 2,468 kali dibandingkan dengan $H$. pylori negatif, walaupun tidak bermakna secara statistik. Hal ini sesuai dengan beberapa literatur yang menyatakan bahwa terdapat hubungan antara infeksi $H$. pylori positif dengan malnutrisi. ${ }^{19,20}$

Penelitian kami mempunyai beberapa keterbatasan, yaitu jumlah sampel dan metode penelitian yang dilakukan. Kami menggunakan metode potong lintang sehingga tidak dapat mengikuti perubahan berat badan dan tinggi badan, serta tidak ada data tinggi badan sebelumnya.

\section{Kesimpulan}

Prevalensi SPB 13,5\% dan prevalensi infeksi $H$. pylori anak SPB 45,4\%. Tidak terdapat perbedaan status gizi dan perawakan pada anak SPB dengan infeksi $H$. pylori positif dan infeksi $H$. pylori negatif. Meskipun demikian, didapatkan proporsi lebih besar pada anak dengan status gizi kurang dengan infeksi $H$. pylori. Perlu dilakukan penelitian lebih lanjut dengan metode penelitian kohort sehingga dapat diikuti apakah infeksi $H$. pylori benar memengaruhi status gizi dan perawakan pendek

\section{Daftar pustaka}

1. Quak S. Recurrent abdominal pain in children: a clinical approach. Singapore Med J 2015;56:125-8.

2. Korterink JJ, Diederen K, Benninga MA, Tabbers MM. Epidemiology of pediatric functional abdominal pain disorders: A meta-analysis. PLoS One 2015;10:1-17. 
Vanda Elfira dkk: Perbedaan status gizi dan perawakan pendek pada anak sakit perut berulang dengan helicobacter pylori positif dan negatif

3. Apley J, Naish N. Recurrent abdominal pains: a field survey of 1,000 school children. Arch Dis Child 1958;33:165-70.

4. Ramchandani PG. The Epidemiology of Recurrent Abdominal Pain From 2 to 6 Years of Age: Results of a Large, PopulationBased Study. Pediatrics 2005;116:46-50.

5. Marie MAM, Ph D. Seroprevalence of Helicobacter pylori Infection in Large Series of Patients in an Urban Area of Saudi Arabia. Kor Soc Gastroenterol 2008;52:226-9.

6. Bravo LE, Mera R, Reina JC, Pradilla A, Alzate A, Fontham E, dkk. Impact of Helicobacter pylori Infection on Growth of Children : A Prospective Cohort Study. J Pediatr Gastroenterol Nutr 2003;614-9.

7. Kocaoglu C, Ozel A, Cayci M, Solak ES. Effect of long-term Helicobacter pylori infection on growth of children: a cohort study. World J Pediatr 2015;1-6.

8. Perri F, Pastore M, Leandro G, Clemente R, Ghoos Y, Peeters $\mathrm{M}$, dkk. Helicobacter pylori infection and growth delay in older children. Arch Dis Child 1997;77:46-9.

9. Windle HJ, Kelleher D, Crabtree JE. Childhood Helicobacter pylori Infection and Growth Impairment in Developing Countries : A Vicious Cycle? Pediatrics 2007;119:754-9.

10. Richter T, Richter T, List S, Müller DM, Deutscher J, Uhlig $\mathrm{HH}$, dkk. Five- to 7-Year-Old Children With Helicobacter pylori Infection Are Smaller Than Helicobacter -Negative Children : A Cross-Sectional Population-Based Study of 3,315 Children. J Pediatr Gastroenterol Nutr 2001;33:4725.

11. Dehghani SM, Karamifar H, Raeesi T, Haghighat M. Growth parameters in children with dyspepsia symptoms and Helicobacter pylori infection. Indian Pediatr 2013;50:324-6.
12. Muttaqin Z, Gunawan S, Soemohardjo S. Laporan penelitian: pengembangan kit diagnostik cepat untuk mendeteksi antibodi Helicobacter pylori (ICT) menggunakan antigen lokal. Mataram: Unit Riset Biomedik RSU Mataram; 2008.

13. Boey CCM, Yap SB, Goh K. The prevalence of recurrent abdominal pain in 11- to 16-year-old Malaysian schoolchildren. J Pediatr 2000;114-6.

14. Rasul C, Khan M. Recurrent abdominal pain in school children in Bangladesh. J Ceylon Coll Physicians 2000;33:110-4.

15. Devanarayana NM, de Silva DGH, de Silva HJ. Recurrent abdominal pain syndrome in a cohort of Sri Lankan children and adolescents. J Trop Pediatr 2008;54:178-83.

16. Soelaeman EJ, Purnomo B, Merati SW, Soehardjo HN, Digdowirogo HS. Infeksi Helicobacter pylori di RSAB Harapan Kita. Sari Pediatri 2004;5:178-80.

17. Prasetyo D, Garna H, Firmansyah A, Idjradina P. Scoring system for Helicobacter pylori infection in children with recurrent abdominal pain. J Indones Med Assoc 2013;38:629-38.

18. Eusebi LH, Zagari RM, Bazzoli F. Epidemiology of Helicobacter pylori Infection. Helicobacter 2014;19:1-5.

19. Soylu ÖB, Ozturk Y. Helicobacter pylori infection : effect on malnutrition and growth failure in dyspeptic children. Eur J Pediatr 2008;167:557-62.

20. Passaro DJ, Taylor DN, Gilman RH, Cabrera L, Parsonnet J. Growth slowing after acute Helicobacter pylori infection. J Pediatr Gastroenterol Nutr 2002;35:522-6.

21. Choe YH, Kim SK, Hong YC. Helicobacter pylori infection with iron deficiency anaemia and subnormal growth at puberty. Arch Dis Child 2000;82:136-40. 